\author{
부비동 병변에 의하여 유발된 일측성 시력 소실 3 예 \\ 아주대학교 의과대학 이비인후과학교실, ${ }^{1}$ 연세대학교 의과대학 이비인후과학교실 ${ }^{2}$ \\ 송정환 ${ }^{1} \cdot$ 윤주헌 $^{2} \cdot$ 김창훈 $^{2} \cdot$ 모정윤 $^{1} \cdot$ 윤용로 $^{1} \cdot$ 김현준 $^{1}$

\section{Three Cases of Unilateral Visual Loss Caused by Sinus Disease} \\ Jung-Whan Song, $\mathrm{MD}^{1}$, Joo-Heon Yoon, $\mathrm{MD}^{2}$, Chang Hoon Kim, $\mathrm{MD}^{2}$, \\ Jung Yun Mo, MD ${ }^{1}$, Yong-Ro Yoon, $\mathrm{MD}^{1}$ and Hyun Jun Kim, MD ${ }^{1}$ \\ ${ }^{1}$ Department of Otolaryngology, Ajou University School of Medicine, Suwon, \\ ${ }^{2}$ Department of Otorhinolaryngology, Yonsei University College of Medicine, Seoul, Korea
}

\begin{abstract}
-ABSTRACT -
Three cases of unilateral visual loss caused by sinus lesion were encountered and we report three cases with literature review. Sinus inflammatory disease like sinusitis or mucocele is a common disease, but visual loss complicated by which is rare. It can be fatal and is known to have a poor prognosis. Appropriate and prompt management like intravenous antibiotics and surgical drainage must be done, when a patient is suspected of having visual loss by sinus problem. We report a case of unilateral visual loss caused by sinusitis, two cases by mucocele. The clinical courses and possible management are discussed. (J Clinical Otolaryngol 2005;16:284-288)
\end{abstract}

KEY WORDS : Blindness $\cdot$ Sinusitis $\cdot$ Mucocele $\cdot$ Orbital disease.

\section{서 론}

부비동의 염증성 병변은 흔한 질환이지만, 항생제 등 여러 가지의 치료약제와 수술적 기법의 발달에도 불구하 고 높은 재발률과 합병증 등 치료에 어려움이 있다. 부 비동의 염증성 병변에 의한 안와합병증은 시력상실, 안구 운동장애 등의 치명적인 합병증이 생길 수 있는데 이는 해부학적으로 안구가 부비동과 얇은 뼈로 분리되어 있어 부비동의 염증이 쉽게 안구로 전파될 수 있기 때문이다. ${ }^{1)}$ 안와에 발생하는 염증의 가장 많은 원인은 부비동염으로 알려져 있으며, 안와 염증의 $75 \%$ 는 부비동의 염증성 병

논문접수일 : 2005년 9월 4일

심사완료일 : 2005년 10월 14일

교신저자 : 김현준, 442- 791 경기도 수원시 영통구 원천동 산 5 아주대학교 의과대학 이비인후과학교실 전화 : (031) 219- 5262. 전송 : (031) 219- 5264

E- mail : entkhj@ajou.ac.kr
변의 합병증으로 발생한다는 보고도 있다. ${ }^{2) 3)}$ 부비동의 염 증성 병변과 관련된 안구합병증이 보고되는 경우에서 드 물게 일시적이나 영구적인 시력 소실을 유발할 수 있다 고 알려져 있으며, 이와 같은 경우는 염증에 의한 직접 적인 시신경손상이나 간접적으로 시신경의 압박으로 인 한 허혈과 관련이 있다고 알려져 있다. ${ }^{4)}$ 점액낭종은 부 비동에 생긴 만성 낭성질환으로 눈 주위에 통증, 안구돌 출, 복시, 시야장애 등의 다양한 증상을 보이며 농성 낭 종일 경우에 안구, 시신경, 또는 주위 구조물에 염증을 전 파하기도 한다. 저자들은 부비동의 염증성 병변에 의하여 영구적인 시력소실을 유발하여 수술적 처치를 시행한 3 예를 임상적 양상과 함께 고찰하고자 한다.

\section{증 례}

증 례 1:

47세 남자환자가 내원 1개월 전에 발생한 우측시력상 

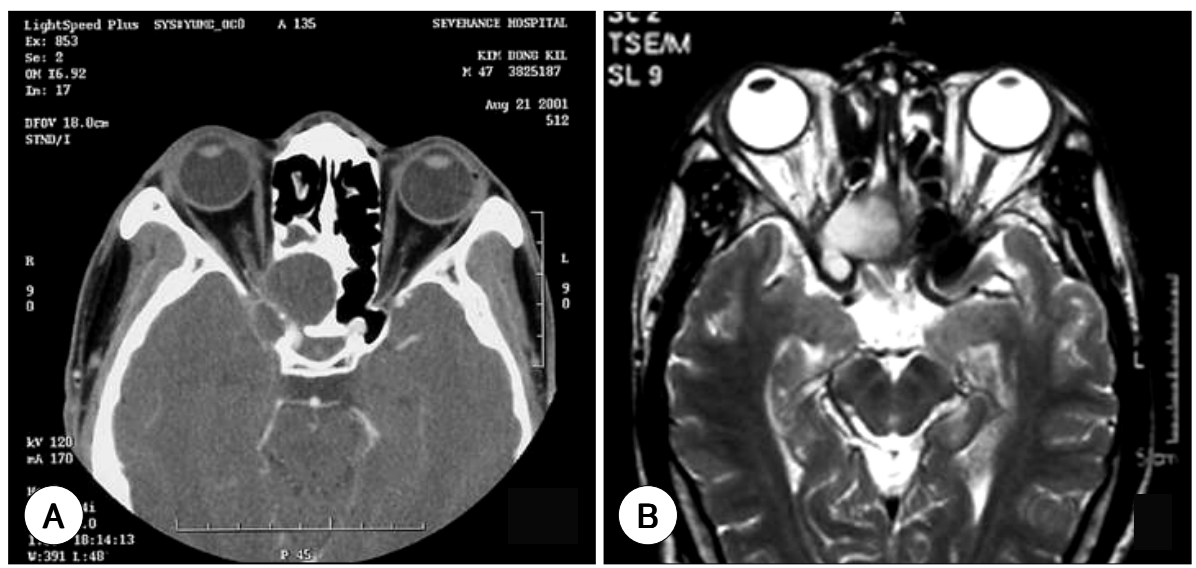

Fig. 1. A : Preoperative axial PNS CT imaging. There is well-defined homogenous, soft tissue density lesion in right ethmoid and sphenoid sinus, suspicious of erosin of right orbit bony wall. B : Preoperative T2 weighted axial imaging shows moderate to high signal intensity lesion in right sphenoid sinus.

실을 주소로 내원하였다. 환자는 과거력상 타병원에서 만 성 부비동염으로 2치례의 Caldwell- Luc operation을 시 행 받은 병력이 있었다. 문진 소견상 좌측 뺨의 통증을 호소하였으나, 그 외 비증상은 없었다. 내원당시 전비경 과 내시경 검사를 이용한 이학적 검사상 양측 사골동절 제술을 시행한 상태였으며 비용종이나 비루는 관찰되지 않았다. 내원 당일 시행한 컴퓨터 단층촬영에서는 양측 시신경과 안구는 정상적으로 관찰되었으며, 우측 안와 골 벽 미란이나 파괴소견이 의심되었으나 명확하지는 않았고, 우측 사골동과 접형동내의 연부 조직음영소견을 보였다. 자기공명영상에서는 우측 사골동과 접형동내에서 T 1 강 조영상에서는 저신호 강도를, T 2 강조영상에서는 변연부 에서는 고신호 강도를 중심부에서는 중등도 또는 고신호 강도를 보였다 Fig. 1). 환자는 우측 접형동 및 사골동염 진단하에 입원하여 정맥항생제 요법을 시행하였고, 내원 2일째에 우측 사골동절제술과 접형동 절개술을 시행하였 다. 수술 소견상 접형동의 전벽 골비후로 인하여 일부 배 농은 시행하였으나 완전 접형동 절개술을 시행하지 못하 였다. 수술 후 환자의 통증 등의 증상은 호전되었으나 시 력의 호전은 관찰되지 않았다. 1 개월 후에 다시 접형동 절개술을 시행하였고, 수술 소견상 접형동 전벽이 비후 되어 있었고 농이 배출되었으며 접형동의 측벽에서 시신 경의 일부 노출 소견을 보였다. 입원기간동안에 정맥항 생제 요법을 시행하였으나 시력은 변화가 없었다. 환자는

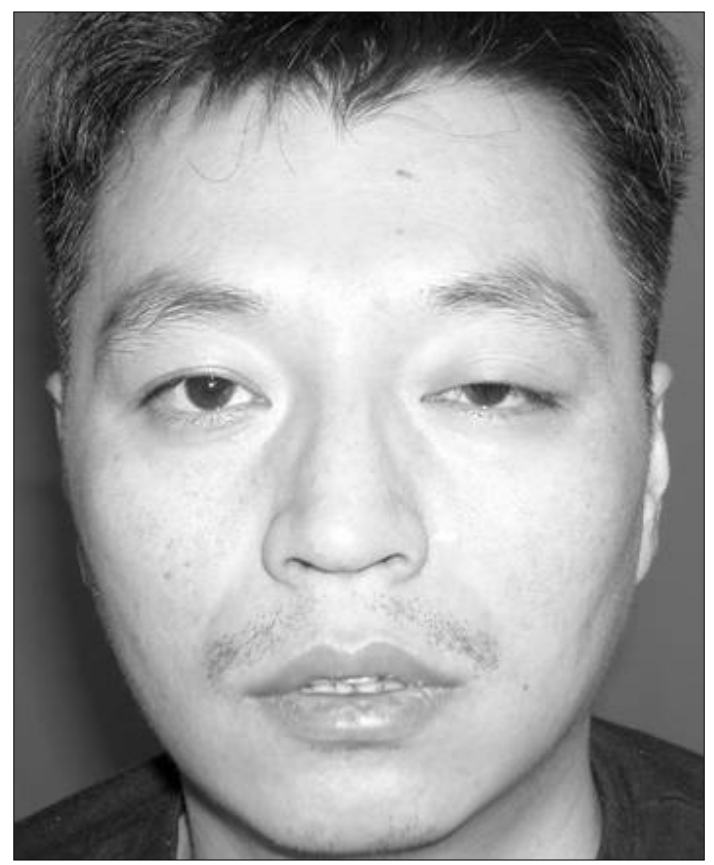

Fig. 2. Preoperative photography shows periorbital swelling.

퇴원하여 외래에서 추적 관찰 중이며, 시력의 호전은 보 이지 않았다.

\section{증 례 2 :}

34세 남자환자가 내원 3일전부터 발생한 좌측 시력상 
실을 주소로 내원하였다. 내원 당시 문진 소견상, 좌측 안 구 주위의 통증과 시력저하를 호소하고 있었고, 이학적 검사상 안구주위 부종, 안구돌출, 안구운동장애의 소견을 보였으며(Fig. 2) 전비경과 내시경 검사에서 비내 점막 종창과 농성 비루소견을 보였다. 내원 당일 시행한 안구 컴퓨터 단층 촬영에서 사골동과 접형동내에 균일한 정도 의 연부조직 종괴소견을 보였으나 그로 인한 골벽미란이 나 파괴소견은 관찰되지는 않았다(Fig. 3). 좌측 후사골

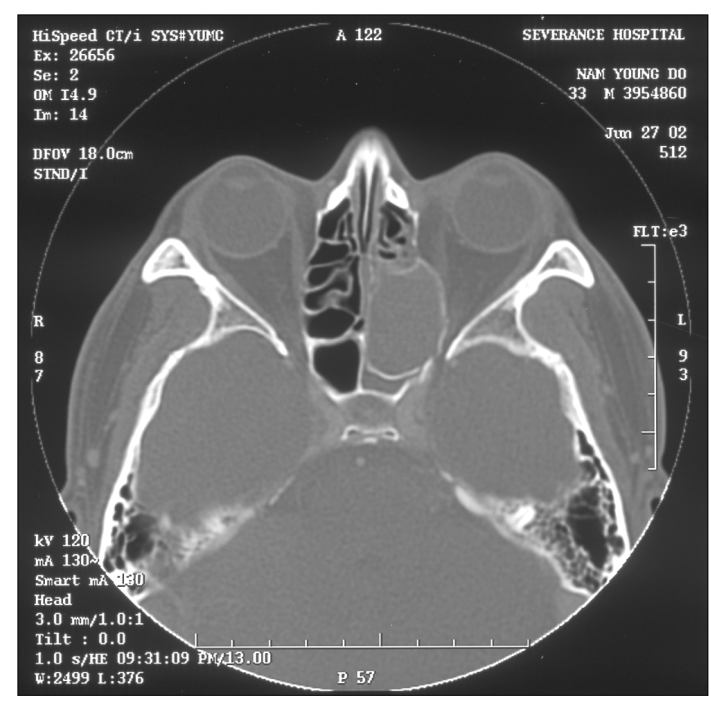

Fig. 3. Preoperative axial PNS CT imaging. There is soft tissue density lesion in left ethmoid sinus without bony erosion or destruction.
동과 접형동의 점액낭종 의심하에 내원 2 일째에 전신 마 취하에 좌측 전, 후 사골동절제술과 접형동 절개술을 시 행 하였다. 수술 소견상 전, 후 사골동절제술과 접형동절 개술시, 염증성 병변과 농배출 소견을 보였으며, 농 제거 후 세척을 시행하였다. 수술직후, 입원기간 도중 스테로이 드와 항생제 정맥요법을 시행하였다. 사골동과 접형동의 종괴에서 나간 조직 생검에서 병리결과는 점액낭종 소견 을 보였다. 수술 직후 비폐색, 비루, 통증 등의 비증상은 호전되었으나 시력은 변화 없었으며, 술 후 시행한 시신 경 유발전위검사에서 좌안은 반응을 보이지 않았으며, 우 안은 정상 소견을 보였다(Fig. 4). 퇴원 후 외래에 추적 관찰 중 비증상은 없었으나, 시력의 향상은 보이지 않았다.

\section{증 례 3 :}

57세 여자환자가 15일전부터 시작된 좌측 시력상실을 주소로 내원하였다. 문진 소견상 비폐색과 농성 비루를 호소하고 있었으며 좌측 시력소실이 있었으며 그 외 특 이 사항은 없었다. 전비경과 내시경 검사에서 비내 점막 종창과 농성 비루소견을 보였으며, 상방과 하방을 주시할 때 안구운동의 제한을 보였고, 타 방향으로의 안구 운동 은 전반적으로 정상적이었다. 내원당시 시행한 자기공명 영상에서는 T1 강조 영상에서는 변연부가 저신호 강도 로 보이는 중등도의 접형동의 종괴 소견이 관찰되었으며, 좌측 시신경과 안구의 압박 소견이 관찰되었다. T 2 강조 영상에서는 고신호 강도의 접형동 종괴 소견을 보였다

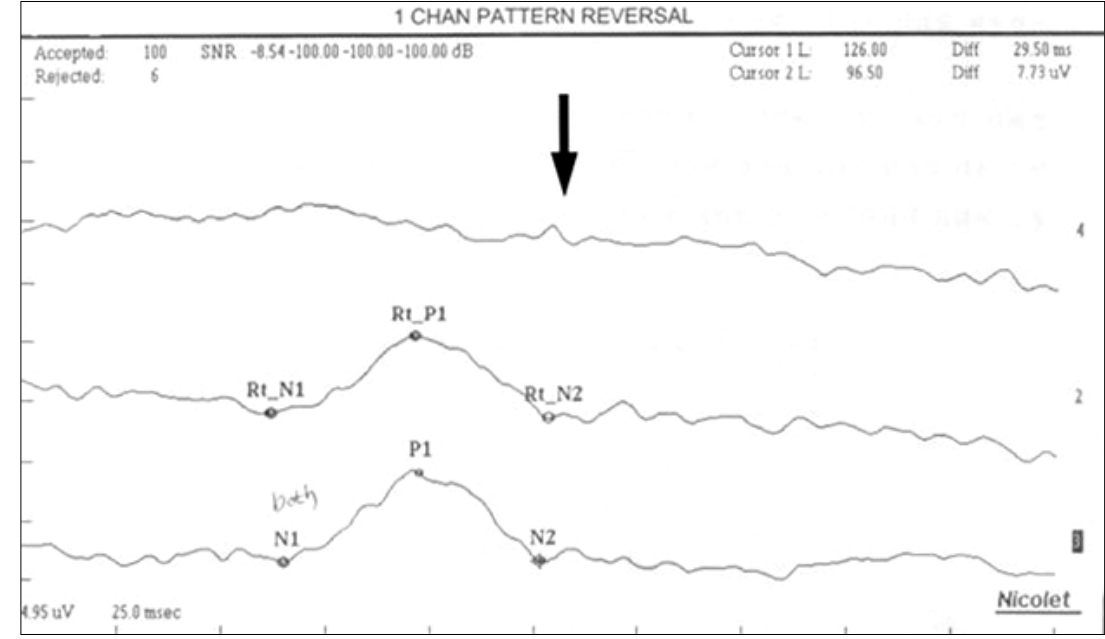

Fig. 4. Visual evoked potential findings shows no response in left eye (arrow). Right eye shows normal response. 
Fig. 5. A : T2 weighted axial image shows moderate signal intensity in left ethmoid and sphenoid sinus, the lesion compressing optic nerve ( arrow) . B : Tl weighted coronal image shows well defined, high signal intensity mass in left ethmoid sinus.

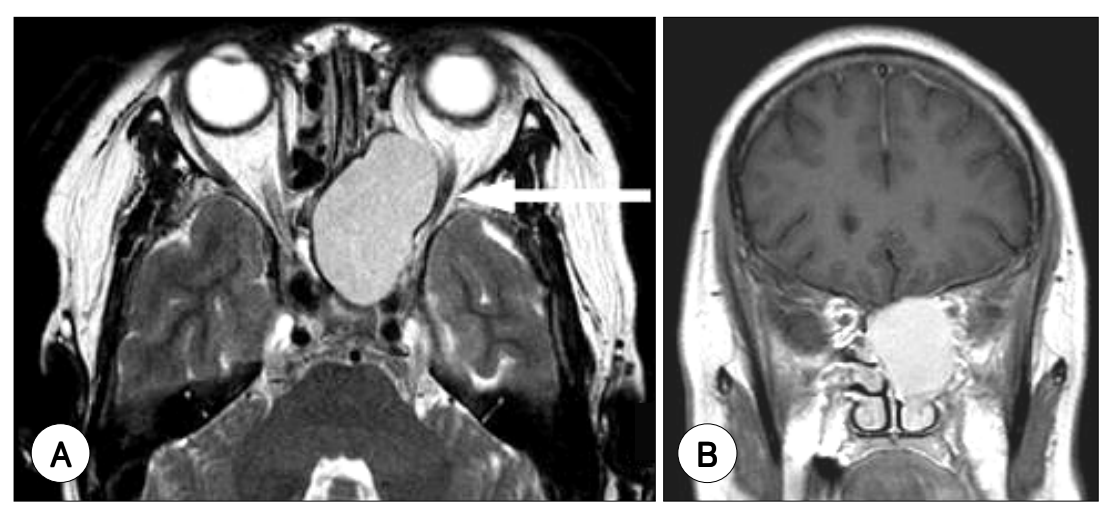

(Fig. 5). 내원당시 시행한 뇌간 유발전위 시력검사에서 좌안은 반응을 보이지 않았으며, 우안은 정상 소견을 보 였다. 환자는 내원 2 일째에 점액낭종 의심하에 접형동 절 개술을 시행하였으며 접형동에서 초록색의 농양이 배출되 어 제거하였다. 접형동내의 종괴에서 나간 조직생검 결과 는 점액 낭종소견을 보였으며, 퇴원 후 외래 추적 관찰에 서 환자는 안구운동장애는 호전되었으나, 시력은 호전되 지 않았다.

\section{고 찰}

부비동 병변의 안와합병증의 증상으로는 안구운동장애, 시력소실, 안구주위 통증, 안구주위종창 등이 있는데 그 중 시력소실이 가장 치명적이고 예후가 나쁘다고 알려져 있다. ${ }^{4)}$ 부비동의 병변에 의한 시력소실은 첫째로, 선천적 혹은 후천적인 골벽자체의 결손부위나 부비동의 염증으로 인한 골벽의 파괴부위를 통한 염증의 안구전파로 인한 시 신경의 손상, 둘째로, 안구 주위의 감염으로 인한 부비 동 염증의 혈행성 전파로 안구 정맥의 혈전성혈관염 또 는 안구시신경염, 마지막으로 점액낭종등의 종괴의 압력 으로 인한 허혈이나 신경의 손상으로 설명되어 진다. ${ }^{3)}$ 과 거 보고들에서는 부비동염에 의해 시신경의 직접 손상으 로 인한 시력상실의 증례 보고는 있으나, 점액낭종에 의 한 경우는 드물다. ${ }^{5)}$

증례 1에서는 방사선학적으로 압박 소견은 없었고 수 술 소견상 시신경의 노출이 관찰되었으므로 시신경의 노 출이 염증에 의한 것인지 아니면 병변과 관계없이 선천적 혹은 후천적으로 발생한 것인지는 알 수 없지만, 염증의
시신경에 직접적인 손상에 의해 시력상실이 유발되었다 고 생각된다. 증례 2에서는 후시골동에서 기원한, 증례 3 에서는 접형동에서 기원한 점액 낭종의 소견이 관찰되었 고 두 증례에서 모두 영상학적 검사에서 골벽의 파괴나 미란 소견이 보이지는 않았지만 병변의 안구압박 소견을 보였으며 수술 소견상 시신경의 노출소견이 보이지 않았 음으로 점액 낭종에 의한 시신경의 압박에 의한 것으로 생각된다.

술 전 진단을 위해 증례 1 에서는 컴퓨터 단층 촬영과 자기공명영상를 모두 시행하였으며, 증례 2에서는 컴퓨 터 단층 촬영만, 증례 3에서는 자기공명영상만을 시행하 였다. 부비동염에 의하여 유발된 시신경병증이 의심되는 환자에게는 컴퓨터 단층 촬영이나 자기공명영상 등의 영 상학적 검사가 필수적이며, 즉시 시행하여야한다.6) 컴퓨 터 단층 촬영은 자기공명영상에 비해 비용이 저렴하며, 각 부비동의 병변을 쉽게 찾아내고, 피질골의 파괴여부를 찾 아내는데 도움을 주며, 내시경으로 접근하기 어려운 병변 을 알아내는 데에도 도움을 준다. ${ }^{6}$ 한편, 자기공명 영상 은 병변 범위와 중추 신경계나 주위안구 조직으로의 침 범 여부를 알아내는데 도움을 준다고 알려져 있다. ${ }^{7)}$

부비동의 염증성 질환에 의하여 유발된 안와 합병증은 응급상황이 될 수 있으므로 진단 당시부터 충분한 항생제 치료가 시작되어야 하며, 약물 치료후 24 48시간 안에 반응을 보이지 않는 경우나, 시력저하 소견이 보이는 경 우, 그리고 농양이 의심되는 경우에는 수술적 치료가 필 요하다. ${ }^{6)}$ 부비동의 염증성 질환에 의하여 유발된 시신 경병증에서 내시경적 부비동 수술은 염증의 근원을 제거 하고 더 이상의 염증의 전파를 막는데 있어서 효과적인 치 
료로 알려져 있으나 시력상실의 회복에는 큰 효과를 보 이지 않는다. 일반적으로 시력 상실은 예후가 좋지 않다 고 보고되어 왔는데, ${ }^{4)}$ 본 증례들에서도 충분한 항생제 치 료와 수술적 치료를 시행하였으나, 시력의 회복은 보이지 않았다.

일반적으로 증상 발생 후 치료가 빠를수록 예후가 좋 다고 알려져 있으며, ${ }^{8)}$ 수술전 시력이 대광반사 없거나 갑 자기 발병한 경우는 예후가 나쁘다. ${ }^{910)}$ 증례 2에서도 갑 자기 발병하였으며 수술 전 대광반사가 없었으므로 시력 이 나쁜 예후를 보인 것으로 생각된다. 본 증례들에서는 증상 발병 시작 후 수술 시행까지 각각 1개월, 5일, 17일 으로 다양하였으나 모두 시력의 회복은 없었다. 수술적 치료까지의 기간의 단축이 시력의 호전을 기대할 수도 있 으나 좀 더 많은 자료의 분석이 필요할 것으로 생각된다. 부비동의 염증성 질환은 흔한 질환이지만 진단 기술의 향상, 항생제의 사용, 내시경을 비롯한 수술 기구나 방법 의 발달로 발생빈도와 합병증은 감소하고 있다. 그러나 비 강과 부비동이 안와와 두개저에 근접하여 있어 항상 주 요 합병증이 발생할 위험성이 있고, 항생제 때문에 합병 증의 증상이 가려져 진단이 어려워 질 수 있기에 주의를 기울여야 한다. 또한 안와내 합병증이 의심되는 환자에서 시력저하의 증상은 일단 발생하면 치명적일 수가 있으므 로 의심되는 즉시 적절한 평가 후 적절한 항생제와 수 술적 치료가 필요할 것이다.
중심 단어 : 시력상실. 부비동염. 점액낭종 안와합병증.

\section{REFERENCES}

1) Levine PA, Frierson HF, Mills SE. Report of the rhinosinusitis task force committee meeting. Otolaryngology-Head Neck Surgery 1997;117 (3 Pt 2):S1-S49.

2) Goodwin Jr WJ, Winshall M, Chandler JR. The role of high resolution computed tomography and standard ultrasound in the evaluation of orbital cellulitis. Laryngoscope 1982;92: $728-31$.

3) Schramm Jr VL, Curtin HD, Kennerdell JS. Evaluation of orbital cellulitis and result of treatment. Laryngoscope 1982; 92:732-8.

4) Pitkaranta A, Atula T, Lindahl P, Saxen H, Malmberg H. Unilateral blindness in a child with acute sinusitis. Rhinology 2000;38:43-4.

5) Kuhn FA, Javer AR. Visual-field loss caused by sinusitis: A case report. ENT-Ear, Nose \& Throat J January 2003;52: 42-5.

6) Chandler JR, Langenbrunner DJ, Stevens E. The pathogenesis of orbital complications in acute sinusitis. Laryngoscope 1999;80:1414-28.

7) Patt BS, Manning SC. Blindness resulting from orbital complication of sinusitis. Otolaryngol Head Neck Surg 1991;104: 789-95.

8) EI-Sayed, Al-Muhaimed H. Acute visual loss in association with sinusitis. J Laryngol Otol 1993;107:840-2.

9) Nerurkar NK, Bradoo R, Muranjan S, Khare M. Sphenoid sinus mucocele with unilateral blindness. Ann Otol Rhinol Laryngol 2004;113(4):294-6.

10) Moriyama H, Hesaka H, Tachibana T, Honda Y. Mucoceles of ethmoid and sphenoid sinus with visual disturbance. Arch Otolaryngol Head Neck Surg 1992;118:1426. 